\title{
Corrigendum: Simplified Assay for Epigenetic Age Estimation in Whole Blood of Adults
}

\section{OPEN ACCESS}

Edited and reviewed by: Rui Henrique, Portuguese Oncology Institute Porto, Portugal

*Correspondence: Antonio Gonzalez agmartinezp@ser.es

Specialty section: This article was submitted to Epigenomics and Epigenetics,

a section of the journal

Frontiers in Genetics

Received: 30 March 2017 Accepted: 10 April 2017 Published: 21 April 2017

Citation:

Vidal-Bralo L, Lopez-Golan Y and Gonzalez A (2017) Corrigendum: Simplified Assay for Epigenetic Age Estimation in Whole Blood of Adults. Front. Genet. 8:51. doi: 10.3389/fgene.2017.00051
Laura Vidal-Bralo, Yolanda Lopez-Golan and Antonio Gonzalez*

Laboratorio Investigacion 10 and Rheumatology Unit, Instituto Investigacion Sanitaria-Hospital Clinico Universitario de Santiago, Santiago de Compostela, Spain

Keywords: epigenetic, biological age, blood, DNA methylation, MS-SnuPE, biomarker

\section{A corrigendum on}

Simplified Assay for Epigenetic Age Estimation in Whole Blood of Adults by Vidal-Bralo, L., Lopez-Golan, Y., and Gonzalez, A. (2016). Front. Genet. 7:126. doi: 10.3389/fgene. 2016.00126

In the original article, there was a mistake in Table $\mathbf{S 1}$ as published. Sequences of the primers to amplify 4 of the CpG sites were wrong. The corrected Table S1 appears below. The authors apologize for this error and state that this does not change the scientific conclusions of the article in any way.

The original article has been updated.

Conflict of Interest Statement: The authors declare that the research was conducted in the absence of any commercial or financial relationships that could be construed as a potential conflict of interest.

Copyright () 2017 Vidal-Bralo, Lopez-Golan and Gonzalez. This is an open-access article distributed under the terms of the Creative Commons Attribution License (CC BY). The use, distribution or reproduction in other forums is permitted, provided the original author(s) or licensor are credited and that the original publication in this journal is cited, in accordance with accepted academic practice. No use, distribution or reproduction is permitted which does not comply with these terms. 
Table S1 | CpGs used in the $8 \mathrm{CpG}$ DmAM, the nearby genes, and the primers and probes used to analyze them.

\begin{tabular}{|c|c|c|c|c|}
\hline CpG & Gene & Primer forward & Primer reverse & Probe \\
\hline cg09809672 & EDARADD & TGAGAAATTAGGAAGATAGTAAATGTTAA & ААТТАТССТСССАССТАСАAАТТСС & TAACCAAACAACCAACIAACATCTTCTC \\
\hline cg24768561 & CENTG2 & GTITGAGGTAAATGGGATIT & СССAACCAATAAACCAACAC & $\begin{array}{l}\text { ATAACTAAAAACAAAAACTCAACCAATATCC } \\
\text { TCAATCCAAAACCTTATAAAACC }\end{array}$ \\
\hline cg16386080 & CDK20 & TTGGGGTAGGGGATTAAGTTAGT & TCCCПППTACATCCAATACAATाT & $\begin{array}{l}\text { gccagcgtcagacatcatatgcagatacCCAA } \\
\text { TACAATIIITAAAACCTACTCATATTCTAAAC } \\
\text { CTACTITAAACC }\end{array}$ \\
\hline cg02228185 & ASPA & АATTATTGGTGAAATGATIIITGTTATA & АATAATТTАСССТССААСССТАТТСТСТА & $\begin{array}{l}\text { GGAGTATTITGGTTAAGTATTGGTTAGA } \\
\text { GAATGG }\end{array}$ \\
\hline cg25809905 & ITGA2B & GGGTाTGTTAGGGGAGTाTा & ПТТСАТССАAТCТТСАACAATAC & $\begin{array}{l}\text { attgatcgtggtgatatccgATAAATAATATACTCAAT } \\
\text { ACTATACCTACITATATTAACCCAC }\end{array}$ \\
\hline cg19761273 & CSNK1D & GGAGGTITGATGTTAGTTGAAG & ТССАСТССТТАТТССТТАСААА & $\begin{array}{l}\text { АACATTCAAATCCAACACAAATAAAAATATT } \\
\text { АACTCCITCTCCAAACC }\end{array}$ \\
\hline
\end{tabular}

All sequences are in the $5^{\prime}-3^{\prime}$ direction. Lowercase bases in probes correspond with non-specific tails. Inosines were used for polymorphic positions. 